ISSN: 1829-6750 Inovasi Kurikulum, Agustus 2009, Thn. 6. Vol 6 Nomor: 2

\title{
EVALUASI DOKUMEN PERENCANAAN PEMBELAJARAN DALAM KONTEKS KURIKULUM TINGKAT SATUAN PENDIDIKAN (KTSP) SEKOLAH MENENGAH KEJURUAN
}

\section{Amay Suherman}

Abstrak: Evaluasi dokumen perencanaan pembelajaran adalah bagian dari jaringan evaluasi dokumen kurikulum secara keseluruhan. Perencanaan pembelajaran tersebut di Sekolah Menengah Kejuruan (SMK) diwujudkan dalam sebuah dokumen Rencana Pelaksanaan Pembelajaran (RPP), maka untuk mengevaluasi dokumen RPP tersebut harus mencermati variabel yang ada dalam RPP. Berdasarkan dokumen Kurikulum Berbasis Kompetensi, dokumen RPP merupakan perwujudan dari rencana implementasi dari salah satu standar kompetensi atau kompetensi dasar yang harus dikuasai siswa. Dalam dokumen KBK berkenaan dengan Kegiatan Belajar Mengajar, hanya tertuang rambu-rambu yang harus diterjemahkan secara operasional oleh masing-masing guru dalam mencapai tuntutan setiap kompetensi yang ada. Didalam dokumen tersebut diberikan contoh bagaimana pencapaian kompetensi, dan contoh kegiatan. Akan tetapi, bagaimana proses pembelajaran yang harus terjadi secara efektif dan efisien harus dirancang oleh guru yang bersangkutan. Untuk itu diperlukan langkah-langkah yang sistematis agar diperoleh kejelasan dan keajegan dalam implementasinya.

Kata Kunci: Evaluasi Dokumen RPP, KTSP.

\section{A. Pendahuluan}

Perencanaan merupakan tugas penting dari suatu organisasi, termasuk

didalamnya organisasi persekolahan. Perencanaan menjadi penting karena pada kenyataannya manusia dapat 
ISSN: 1829-6750 Inovasi Kurikulum, Agustus 2009, Thn. 6 . Vol 6 Nomor: 2

mengubah masa depan apabila sesuatunya itu direncanakan dengan baik dan secara matang, demikian pula yang terjadi dalam konteks pembelajaran secara lebih luas dalam pendidikan. Perencanaan dalam rangka proses pembelajaran (perencanaan pembelajaran) harus berorientasi pada pencapaian tujuan pendidikan yang ingin dicapai.

Dalam sebuah rencana pembelajaran, selain harus dirumuskan tujuan yang ingin dicapai (sasaran kompetensi), juga harus jelas cakupan dan urutan materi yang mendukung, serta cara yang akan ditempuh (skenario yang akan dan harus diperankan oleh guru-siswa) untuk mencapai tujuan tersebut. Skenario yang dirumuskan tersebut, di-maksudkan guna mem-fasilitasi siswa dalam menguasai kompetensi (melalui proses evaluasi) yang menjadi sasaran pembelajaran. Dengan demikian berarti bahwa; (1).
Perencanaan melibatkan proses penentuan tujuan yang diinginkan. (2). Penilaian dan penentuan cara yang akan ditempuh dengan melihat berbagai alternatif. dan (3). Usaha mencapai tujuan tersebut.

Perencanaan pembelajaran merupakan langkah utama yang penting, yang harus dilakukan oleh guru. Dengan dibuatkannya perencanaan pembelajaran, paling tidak: (1) arah dalam usaha-usaha pembelajaran menjadi jelas; (2) dapat diketahui apakah tujuan tersebut telah dicapai atau belum; (3) dapat diidentifikasi hambatanhambatan yang mungkin timbul dalam pelaksanaannya, dan (4) dapat dihindari segala sesuatu yang terjadi di luar perencanaan/tujuan yang diharapkan.

\section{B. Mengapa Perencanaan Pembelajaran Penting?}

Jawabannya adalah kembali kepada pandangan yang dijadikan pegangan tentang 
ISSN: 1829-6750 Inovasi Kurikulum, Agustus 2009, Thn. 6 . Vol 6 Nomor: 2

apakah belajar, apakah mengajar, apakah jabatan guru itu profesi atau bukan. Kalau berpegang pada pengertian belajar sebagai proses perubahan perilaku individu sebagai akibat interaksi dengan lingkungannya, maka dengan pengertian tersebut muncul pertanyaan berikutnya yaitu apakah yang dimaksud dengan perilaku itu? Perubahan perilaku bagaimana yang termasuk belajar, apakah perubahan perilaku dapat terjadi pada setiap individu yang berinteraksi dengan sejauhmana perilaku itu berubah, pada aspek apa saja? Siapa yang bertangggung jawab atas perubahan atau tidak terjadi perubahan perilaku pada individu, bagaimana perubahan positifnegatif dari perilaku individu?

Dengan berpegang pada pengertian mengajar sebagai segala upaya sadar yang disengaja dalam rangka memberikan kemungkinan bagi siswa untuk terjadinya proses belajar sesuai dengan tujuan yang telah dirumuskan, maka sasaran akhir proses pembelajaran itu sendiri adalah siswa yang belajar. Oleh karena itu, upaya apapun dapat dilakukan asalkan upaya itu disengaja dengan penuh rasa tanggung jawab untuk mengantarkan siswa menuju pencapaian tujuan. Tujuan itu dicapai melalui proses pembelajaran, adapun ke-mungkinan terjadinya proses belajar itu sendiri amat beraneka ragam.

Guru di sekolah atau pada lembaga pendidikan merupakan faktor pertama dan utama. Terlepas dari keterbatasan waktu belajar di sekolah (keterlibatan langsung guru-siswa), tetapi proses belajar yang sangat berpengaruh terhadap individu adalah proses belajar di sekolah yang dibimbing oleh guru. Tidak dapat disalahkan apabila orang tua siswa dan masyarakat pada umumnya memberikan 
ISSN: 1829-6750 Inovasi Kurikulum, Agustus 2009, Thn. 6 . Vol 6 Nomor: 2

kepercayaan yang besar dan sepenuhnya pada guru. Dengan demikian, guru tidak dapat mundur (mengelak) dalam melakukan jabatannya. Oleh karena itu, dalam melaksanakan tugas dan kewajibannya, seorang guru harus melakukannya dengan suatu perencanaan yang optimal, penuh tanggung jawab dan profesional.

Apa perbedaan antara perencanaan pembelajaran dengan perencanaan bidang lain, misalnya bidang teknologi. Seorang disainer/ perencana bidang teknologi akan dapat membuat suatu perencanaan apabila dia menguasai dasar-dasar perencanaan, di antaranya: ilmu kekuatan bahan, teknik pengerjaan, perhitungan dan sebagainya.

Dengan dukungan ilmu-ilmu tersebut, dia akan menghasilkan suatu perencanaan benda teknik yang akan digunakan pada penggunaan tertentu, dengan kemampuan tertentu, daya tahan tertentu dengan tingkat presisi pengerjaan tertentu. Orang yang mempunyai kemampuan ini mendapat kehormatan tertentu dan dipandang sebagai seorang profesional.

Apakah seseorang perencana pembelajaran

bisa mendapatkan penghargaan seperti peren-cana bidang teknologi? Apakah dengan begitu saja dapat membuat suatu perencanaan tanpa menguasai konsep-konsep dasar ilmu yang menunjang perencana pembelajaran tersebut? Seorang perencana pembelajaran yang profesional baru akan dapat membuat suatu perencanaan apabila menguasai ilmu-ilmu yang menunjangnya, di antaranya: Landasan/filsafat pendidikan, psikologi perkembangan peserta didik, pengembangan kurikulum, strategi belajar mengajar, media pendidikan, evaluasi pendidikan dan sebagainya tentunya tidak lepas dari penguasaaan bidang studi sebagai bahan ajar sesuai 
ISSN: 1829-6750 Inovasi Kurikulum, Agustus 2009, Thn. 6. Vol 6 Nomor: 2

dengan keahliannya. Hal ini berarti bahwa perencanaan pembelajaran tidak dapat dilakukan tanpa dasar dan tidak mudah. Hanya orang yang profesional yang dapat melakukannya.

Dengan demikian seorang yang mampu membuat perencanaan pembelajaran pantas mendapat

penghargaan seperti juga perencana dalam bidang teknologi dan sebagainya. Artinya guru yang ingin dihargai harus melakukan jabatannya secara profesional, termasuk dalam kemampuan pembuatan perencanaan pembelajaran.

Bentuk hasil perencanaan pembelajaran berupa konsep, yang dalam implementasinya dapat melibatkan guru dengan atau tanpa media, atau dengan media tanpa keterlibatan langsung dari guru, (misalnya pengerjaan pengajaram berprogram, modul, computer assisted instruction (CAI) dan sebagainya). Perencanaan pembelajaran hasilnya dapat bervariasi dilihat dari berbagai aspek yang mempengaruhi timbulnya variasi hasil perencanaan pembelajaran. Hal tersebut dapat terjadi oleh dua faktor, yaitu faktor perencana dan faktor di luar perencana. Faktor-faktor dari perencana yang berpengaruh adalah kepribadian dan penguasaaan ilmu-ilmu yang diperlukan dalam membuat perencanaan. Kepribadian perencana yang mungkin berpengaruh adalah pandangan/persepsi

perencana tentang pendidikan, belajar, siswa, mengajar, perencanaan pembelajaran, tipe kepemimpianan ("laissez faire, demokrasi, otoriter") dan sebagainya. Sementara itu, penguasaan perencana terhadap ilmu-ilmu atau konsep-konsep yang diperlukan dalam membuat perencanaan pembelajaran, misalnya: penguasaan bidang studi (mencakup keluasan dan kedalamannya), pe-mahaman terhadap tujuan pendidikan dan pembelajaran, landasan- 
ISSN: 1829-6750 Inovasi Kurikulum, Agustus 2009, Thn. 6 . Vol 6 Nomor: 2

landasan pendidikan, teori belajar, psikologi pendidikan, pe-ngembangan kurikulum, strategi belajar-mengajar, evaluasi pendidikan dan sebagainya. Sementara itu, faktor di luar perencana yang juga mempengaruhi perencanaan meliputi:

1. Tingkat lembaga pendidikan (SD, SLP. SMU, PT).

2. Macam jenis pendidikan (formal, non formal).

3. Pesan-pesan yang terkandung dalam kurikulum (pembentukan karakteristik tertentu dari peserta didik).

4. Kaidah-kaidah pendidikan, teori belajar yang dijadikan acuan (mementingkan produk atau mementingkan proses).

5. Peserta didik (karakteristik peserta didik).

6. Tingkat dan jenis tujuan (aspek dari kompetensi) yang ingin dicapai.
7. Tipe-tipe materi pelajaran misalnya, teori (berupa fakta, konsep dan prinsip), hitungan, gambar atau praktek (praktek untuk mempertinggi pemahaman atau untuk menghasilkan skill).

8. Tipe-tipe belajar.

9. Prinsip-prinsip mengajar yang dipergunakan.

10. Sarana yang tersedia.

11. Kondisi umum, dan lainlain.

\section{Kompetensi dalam Konteks Perencanaan Pembelajaran}

Konsep kompetensi menurut Majelis Pendidikan Kejuruan Nasional (1999) diartikan sebagai suatu kemampuan yang didasari oleh pengetahuan (knowledgel ranah kognitif), keterampilan (skill/ranah psikomotor), dan didukung oleh sikap kerja (aptitude/ranah afektif) serta 
ISSN: 1829-6750 Inovasi Kurikulum, Agustus 2009, Thn. 6. Vol 6 Nomor: 2

penerapannya dalam me- dikatakan kompeten dalam laksanakan suatu tugas/ suatu bidang (mata pelajaran) pekerjaan di tempat kerja adalah yang memiliki dengan mengacu pada kriteria pengetahuan, keterampilan, unjuk kerja yang dipersyaratkan. Kompetensi juga dapat diartikan sebagai kemampuan melaksanakan tugas yang diperoleh melalui pendidikan dan pelatihan, yang mencakup aspek pengetahuan, keterampilan, dan sikap.

Berdasarkan sumber lain, yakni dari Pusat Kurikulum, Balitbang Depdiknas (2002); Kompetensi diartikan sebagai pengetahuan, keterampilan, dan nilai-nilai dasar yang direfleksikan dalam kebiasaan berpikir dan bertindak. Kebiasaan berpikir dan bertindak secara konsisten dan terus-menerus memungkinkan seseorang menjadi kompeten, dalam arti memiliki pengetahuan, keterampilan, dan nilai-nilai dasar untuk melakukan sesuatu. Dengan demikian, jelaslah bahwa yang dimaksud dengan seseorang dan nilai/sikap secara terintegrasi, secara proporsional, yakni sesuai dengan level atau tingkatan kompetensi yang dimaksud. Artinya, untuk setiap ranah yang membentuk kompetensi (kognitif, afektif, dan psikomotor) tuntutannya harus dikuasai secara tuntas (mastery). Hal inilah yang menjadi tantangan positif bagi setiap guru dalam menterjemahkan/mengejewan tahkan tuntutan Kurikulum Berbasis Kompetensi. Untuk itu, para guru dituntut mampu merancang pembelajaran berdasarkan tuntutan kompetensi, baik untuk ranah kognitif, afektif maupun psikomotor secara proporsional.

Gambaran mengenai tingkat atau level dari setiap ranah, baik ranah kognitif, afektif, maupun psikomotor, berdasarkan taksonomi Bloom 
ISSN: 1829-6750 Inovasi Kurikulum, Agustus 2009, Thn. 6 . Vol 6 Nomor: 2

(2002), dapat dipaparkan Level atau tingkatan dari sebagai berikut: setiap ranah tersebut di atas, bersifat kulminatif. Artinya, untuk mencapai suatu level

\section{Ranah Kognitif}

harus melalui level

1. Level Pengetahuan;

sebelumnya.

Dengan

2. Level Pemahaman;

3. Level Aplikasi;

4. Level Analisis - Sinthesis;

5. Level Evaluasi; dan

6. Level Berpikir Kreatif ("Create").

\section{Ranah Afektif}

1. Level Menerima;

2. Level Merespons;

3. Level Menilai;

4. Level Mengorganisasi Nilai; dan

5. Level Mewatak

\section{Ranah Psikomotor}

1. Level Persepsi;

2. Level Kesiapan;

3. Level Respons Terbimbing/Peniruan;

4. Level Mekanisme;

5. Level Respons Kompleks;

6. Level Adaptasi; dan

7. Level Originasi.

demikian, seseorang yang telah menguasai/mencapai suatu level, merupakan gambaran kulminasi penguasaan materi atau keterampilan yang ditempuh secara berurutan.

Level dari ranah kognitif yang membangun kompetensi tersebut, berkaitan dengan penyusunan rencana pembelajaran atau rencana pelaksanaan pembelajaran yang menyangkut jumlah dan kualitas informasi yang harus disampaikan kepada siswa. Untuk ranah psikomotor, menyangkut jumlah jam atau kesempatan latihan dari suatu tuntutan kompetensi (jam terbang), sedangkan untuk ranah afektif, menyangkut penanaman kesadaran untuk mentaati ketentuan yang berlaku pada standar kompetensi atau kompetensi 
ISSN: 1829-6750 Inovasi Kurikulum, Agustus 2009, Thn. 6 . Vol 6 Nomor: 2

dasar yang bersangkutan (Standar

Operasional

Prosedur/SOP).

Selain harus jelas dalam merumuskan tujuan pembelajaran yang berkaitan dengan pencapaian standar kompetensi atau kompetensi dasar, dalam menyusun suatu rencana pembelajaran seorang guru selain harus memperhatikan rambu-rambu tuntutan kurikulum seperti pendekatan belajar, sarana pendukung proses pembelajaran yang diperlukan baik jumlah maupun kualifikasinya, demikian pula harus memperhatikan modalitas belajar anak. Pada prinsipnya, pada kondisi apapun guru dituntut untuk mampu melayani atau memfasilitasi anak/peserta didik dalam mencapai tuntutan kompetensi yang ada. Oleh karena itu, setiap ranah sesuai dengan tuntutannya harus dirancang skenario pembelajarannya dengan jelas. Artinya, apa yang harus dipersiapkan guru (pendekatan, metode, media, atau sumber belajar) dalam rangka mengkondisikan siswa belajar harus tercantum secara jelas dalam skenario pembelajaran. Demikian pula, apa yang harus siswa kerjakan/lakukan dalam rangka mencapai tuntutan kompetensi yang dimaksud harus secara jelas tercantum dalam skenario pembelajaran.

\section{Langkah-langkah Evaluasi Dokumen Rencana Pelaksanaan Pembelajaran}

Langkah-langkah evaluasi dokumen perencanaan pengajaran, dimana perencanaan pembelajaran tersebut diwujud-kan dalam sebuah dokumen Rencana Pelaksanaan Pem-belajaran (RPP), maka untuk mengevaluasi dokumen RPP perwujudan dari rencana implementasi dari salah satu standar kompetensi atau kompetensi dasar yang harus dikuasai siswa. 
ISSN: 1829-6750 Inovasi Kurikulum, Agustus 2009, Thn. 6. Vol 6 Nomor: 2

\section{Tabel. 1 : Langkah-langkah yang harus ditempuh guru dalam rangka kelancaran proses pembelajaran, salah satu alternatifnya}

Format (bentuk matriks) RPP Berbasis Kompetensi

SMK

Program Keahlian

Standar Kompetensi

Tujuan Pembelajaran

\begin{tabular}{|c|c|c|c|c|c|}
\hline $\begin{array}{l}\text { KOMP } \\
\text { E- } \\
\text { TENSI } \\
\text { DASA } \\
\text { R }\end{array}$ & $\begin{array}{l}\text { INDIKATOR/ } \\
\text { KRITERIA } \\
\text { KINERJA }\end{array}$ & $\begin{array}{l}\text { SKENARIO/LA } \\
\text { NGKAH } \\
\text { PEMBELAJAR } \\
\text { AN }\end{array}$ & $\begin{array}{c}\text { HASIL } \\
\text { PEMBELAJAR } \\
\text { AN }\end{array}$ & EVALUASI & KET. \\
\hline $\begin{array}{l}\text { Kompe } \\
\text { tensi } \\
\text { Dasar } \\
\text { A1 }\end{array}$ & $\begin{array}{l}\text { - } \begin{array}{l}\text { Pengetahuan } \\
\text { (Kognitif) }\end{array} \\
\text { - } \begin{array}{l}\text { Keterampilan } \\
\text { (Psikomotor) }\end{array} \\
\text { - Sikap Kerja } \\
\text { (Apektif) }\end{array}$ & $\begin{array}{l}\text { Gambaran } \\
\text { komunikasi guru - } \\
\text { siswa yang } \\
\text { berpusat pada } \\
\text { kegiatan siswa } \\
\text { (student center), } \\
\text { untuk setiap } \\
\text { indikator dasi } \\
\text { setiap ranah }\end{array}$ & $\begin{array}{l}\text { Perubahan } \\
\text { perilaku siswa, } \\
\text { yang } \\
\text { menggambarkan } \\
\text { pencapaian } \\
\text { kompetensi. } \\
\text { Parameternya } \\
\text { penguasaan setiap } \\
\text { indikator oleh } \\
\text { siswa dari masing- } \\
\text { masing ranah } \\
\text { secara tuntas }\end{array}$ & $\begin{array}{l}\text { Dikembangkan } \\
\text { untuk setiap } \\
\text { indikator dari } \\
\text { masing-masing } \\
\text { ranah. Untuk ranah } \\
\text { kognitif (essay dan } \\
\text { atau obyektif). } \\
\text { Untuk ranah } \\
\text { psikomotor (lembar } \\
\text { observasi dan } \\
\text { standar spesifikasi } \\
\text { atau akurasi/presisi). } \\
\text { Untuk ranah afektif } \\
\text { SOP }\end{array}$ & $\begin{array}{l}\text { Untuk } \\
\text { mencantumkan } \\
\text { referensi yang } \\
\text { dijadikan } \\
\text { rujukan. } \\
\text { Mencantumkan } \\
\text { media yang } \\
\text { digunakan. } \\
\text { Mencantumkan } \\
\text { metode yang } \\
\text { digunakan }\end{array}$ \\
\hline \multicolumn{6}{|l|}{$\begin{array}{l}\text { Kompe } \\
\text { tensi } \\
\text { Dasar } \\
\text { A2 }\end{array}$} \\
\hline Dst. & & & & & \\
\hline
\end{tabular}


ISSN: 1829-6750 Inovasi Kurikulum, Agustus 2009, Thn. 6 . Vol 6 Nomor: 2

Dalam dokumen KBK berkenaan dengan Kegiatan Belajar Mengajar, hanya tertuang rambu-rambu yang harus diterjemahkan secara operasional oleh masingmasing guru dalam mencapai tuntutan setiap kompetensi yang ada. Didalam dokumen tersebut diberikan contoh bagaimana kompetensi dan contoh kegiatan. Akan tetapi bagaimana proses pembelajaran yang harus terjadi secara efektif dan efisien harus dirancang oleh guru yang bersangkutan. Untuk itu diperlukan langkah-langkah yang sistematis agar diperoleh kejelasan dan keajegan dalam implemen-tasinya.

\section{Indikator Evaluasi Dokumen RPP:}

- Tujuan Pembelajaran; harus diisi/dirumuskan secara komprehensif menggambarkan pencapaian standar kompetensi ataupun kom- petensi dasar yang akan diajarkan, dengan mencantumkan pencapaian level atau tingkat setiap aspek/ranahnya.

- Kolom Kompetensi Dasar; harus diisi dengan kompetensi dasar yang bersangkutan yang menggambarkan materi pembelajaran untuk dipelajari oleh siswa.

- Kolom Indikator/Kriteria Kinerja; harus diisi dengan deskripsi indikator/kriteria kinerja, yang menggambarkan cakupan dan urutan sistematis materi dari kompetensi dasar, yang harus dikuasai oleh siswa. Dalam kolom ini harus tergambarkan:

1. Cakupan (scope) dan urutan (sequence) materi teori (untuk ranah kognitif) dari tuntutan kompetensi dasar yang bersangkutan;

2. Urutan langkah praktik (untuk ranah psikmotor), mulai dari: (a) persiapan, (b) proses kerja, (c) sikap 
kerja, (d) hasil kerja yang ditargetkan, dan (e) waktu yang dialokasikan berdasarkan tuntutan standar kompetensi yang bersangkutan;

3. Ketentuan-ketentuan (untuk ranah apektif) yang terkait dengan tuntutan standar operasional prosedur (SOP) dari standar kompetensi/kompetensi dasar.

- Kolom Skenario/Langkahlangkah Pembelajaran; harus diisi dengan kegiatan yang akan dilakukan guru dan siswa, untuk mencapai penguasaan standar kompetensi/kompetensi dasar tertentu. Dalam kolom skenario pembelajaran ini, berisi gambaran kegiatan yang akan dilaksanakan oleh guru dalam rangka memfasilitasi siswa untuk menguasai tuntutan standar kompetensi.

Skenario/langkah pembelajaran ini, secara garis besar terdiri dari tiga fase, yakni: (1) Pra KBM, menggambarkan aktivitas awal kegiatan pembelajaran, di antaranya pengkondisian siswa untuk memulai proses belajar, aplikasi siasat membuka pelajaran; (2) KBM Inti, yakni menggambarkan aktivitas guru-siswa yang harus berpusat pada siswa (student center) dalam rangka mencapai semua indikator dari masingmasing ranah. Pencapaian semua indikator tersebut merupakan gambaran ketuntasan yang harus dicapai siswa, yakni sebagai standar minimal dari tuntutan standar kompetensi. Dalam rumusan skenario pembelajaran (KBM Inti) ini tergambar penerapan/ penggunaan "metode" secara implisit, dan penggunaan "media" secara eksplisit. Selain itu, dalam setiap rumusan langkah pembelajaran perlu 
ISSN: 1829-6750 Inovasi Kurikulum, Agustus 2009, Thn. 6. Vol 6 Nomor: 2

dicantumkan alokasi waktu yang diperkirakan akan dibutuhkan; (3) Pasca KBM (Penutup), yakni menggambarkan akhir dari suatu proses pembelajaran untuk satu periode pertemuan. Langkah yang dapat ditempuh dalam Pasca KBM ini, di antaranya merangkum/ menyimpulkan materi yang telah disampaikan, memberikan kesempatan kepada siswa apabila masih ada materi yang kurang jelas atau belum dikuasai, memberikan

tugas terstruktur berupa tugastugas untuk memantapkan penguasaan materi yang bersangkutan,

menginformasikan materi yang berikutnya.

- Kolom Hasil Pembelajaran, harus diisi dengan target hasil yang harus dicapai dari setiap rumusan langkah pembelajaran, baik dari ranah kognitif (untuk materi teori), dari ranah psikmotor (untuk materi praktik), maupun dari ranah afektif (standar operasional prosedur/SOP) berkaitan tuntutan standar kompetensi yang bersangkutan.

- Kolom Evaluasi, harus diisi dengan gambaran bentuk dan jenis evaluasi yang akan digunakan dalam mengevaluasi kompetensi siswa. Dalam kolom evaluasi ini juga harus tergambar butir-butir soal dari setiap indikator atau sasaran hasil pembelajaran, yang harus dikuasai oleh siswa. Untuk ranah kognitif, bentuk butir soal dapat berupa esai ataupun tes obyektif dengan berbagai jenisnya. Untuk ranah psikomotor, terdiri dari evaluasi proses (dengan lembar observasi) dan evaluasi hasil, yakni ada yang berupa "spesifikasi standar" ataupun berupa "bentuk dan presisi" hasil pekerjaan. Untuk ranah afektif, berupa evaluasi 
ISSN: 1829-6750 Inovasi Kurikulum, Agustus 2009, Thn. 6 . Vol 6 Nomor: 2

proses (dengan lembar observasi) yakni merupakan standar operasional prosedur dari tuntutan standar kompetensi/kompetensi dasar yang bersangkutan.

- Kolom Keterangan, harus diisi dengan hal-hal yang belum teridentifikasi, yang perlu mendapat perhatian dalam sebuah rencana pelaksanaan pembelajaran. Dalam kolom tersebut dapat dicantumkan referensi yang dijadikan rujukan dalam penyampaiaan materi pelajaran tersebut. Selain itu, dapat dicantumkan media pembelajaran yang akan digunakan, demikian pula metode yang akan digunakan dalam proses pembelajaran tersebut.

Sementara itu, panduan yang harus diperhatikan dalam menyusun RPP untuk Kurikulum Berbasis Kompetensi (sekarang diwujudkan dalam Kurikulum Tingkat Satuan Pendidikan/KTSP) "harus" memperhatikan prinsip-prinsip pembelajaran berbasis kompetensi. Prinsipprinsip pembelajaran berbasis kompetensi

(http://www.prima-sanjayasrg.sch.id) adalah sebagai berikut:

- Tujuan pembelajaran jelas.

- Pembelajaran berfokus pada peserta diklat.

- Menekankan pada penguasaan kompetensi.

- Menekankan pada pencapaian performansi.

- Menggunakan strategi pembelajaran yang dapat mengakomodasi cara belajar yang bervariasi.

- Menggunakan metode pembelajaran yang bersifat learning by doing.

- Pembelajaran bersifat individual dilakukan dengan menggunakan modul.

- Memperhatikan kebutuhan dan kecepatan belajar peserta diklat secara individu. 
ISSN: 1829-6750 Inovasi Kurikulum, Agustus 2009, Thn. 6 . Vol 6 Nomor: 2

- Media dan materi yang digunakan didesain untuk membantu pencapaian kompetensi.

- Kegiatan pembelajaran hendaknya memperhatikan kemudahan proses pemonitoran untuk memudahkan pengaturan program belajar.

- Kegiatan pembelajaran diadministrasikan.

- Memanfaatkan sumberdaya internal dan eksternal sekolah.

- Pembelajaran dapat dilakukan di dalam dan di luar sekolah.

- Lingkungan belajar dikondisikan seperti di dunia kerja.

- Melakukan penilaian hasil belajar untuk mendapatkan umpan balik.

- Penilaian dilakukan terhadap performansi yang dicapai dengan cara demonstrasi.

- Tingkat performansi peserta diklat ditentukan dengan membandingkan kriteria unjuk kerja sesuai dengan kompetensi yang akan dicapai.

\section{E. Penutup}

Berdasarkan prinsip-prinsip pembelajaran berbasis kompetensi tersebut, dalam menyusun rencana pelaksanaan pembelajaran, seorang guru dituntut untuk dapat menterjemahkan prinsip-prinsip tersebut kedalam dokumen rencana pelaksanaan pembelajaran tersebut. Dengan demikian, apa yang akan ditampilkan oleh guru di dalam kelas sudah harus tergambar dalam dokumen RPP yang dikebangkan. Artinya, dokumen RPP tersebut merupakan "panduan" guru yang bersangkutan dalam melaksanakan tugasnya di kelas/tempat praktek.

Berkaitan dengan penyusunan RPP ini, yang menjadi tugas profesional bagi seorang guru yakni dimulai dalam merumuskan tujuan pembelajaran (mengacu 
ISSN: 1829-6750 Inovasi Kurikulum, Agustus 2009, Thn. 6 . Vol 6 Nomor: 2

kepada standar kompetensi atau kompetensi dasar), mendeskripsikan indikator/ kriteria kinerja untuk setiap aspek/ranah kompetensi (kognitif, afektif, psikomotor) dari tuntutan standar kompetensi atau kompetensi dasar. Selanjutnya, guru dituntut untuk memiliki kemampuan dalam merumuskan "skenario pembelajaran" atau langkah-langkah pembelajaran yang terdiri dari langkah: $\quad$ Pra KBM; KBM Inti; dan Pasca KBM (Menutup Pelajaran).

Berkaitan dengan perumusan skenario pembelajaran, seorang guru harus mampu menggambarkan apa yang akan dilaksanakan oleh guru di kelas, dalam rangka memfasilitasi siswa menguasai kompetensi yang bersangkutan. Dalam merumuskan skenario pembelajaran, seorang guru harus menentukan metode dan media apa yang akan diterapkan dalam proses pembelajaranya. Penetapan metode dan media pembelajaran tersebut sudah barang tentu harus mempertimbangkan, di antaranya: karakteristik materi yang akan disampaikan, karakteristik siswa, dan kemampuan guru yang bersangkutan dalam mengimplementasikan metode dan mengoperasikan media tersebut. Selanjutnya, guru harus mempertimbangkan kebutuhan sumber belajar yang harus ada, baik di sekolah maupun di sekitarnya, dalam rangka kelancaran proses pencapaian kompetensi yang dimaksud.

Selain tuntutan di atas, dalam penyusunan RPP ini, seorang guru dituntut untuk merancang alat evaluasi dalam rangka uji kompetensi secara proporsional. Untuk alat evaluasi ranah kognitif dapat berbentu esai ataupun berbentuk obyektif dengan berbagai jenis. Untuk alat evaluasi ranah afektif dapat 
ISSN: 1829-6750 Inovasi Kurikulum, Agustus 2009, Thn. 6 . Vol 6 Nomor: 2

berupa lembar observasi ataupun pedoman wawancara. Untuk alat evaluasi ranah psikomotor dapat berupa lembar observasi (untuk evaluasi proses) dan evaluasi hasil, yakni ada yang berupa "spesifikasi standar" ataupun berupa "bentuk dan presisi" hasil pekerjaan. Secara menyeluruh, evaluasi berbasis kompetensi dapat diformulasikan dalam bentuk portofolio.

\section{Daftar Pustaka}

Burden, P.R. and Byrd, D.M. (1999). Method for Effective Teaching: Second Edition, USA: Allyn and Bacon

Depdiknas. (2004) Kurikulum SMK Edisi 2004, Jakarta: Dikmenjur

.(2003) Penilaian Tingkat Kelas, Jakarta: Pusat Penilaian Pendidikan.
.2002 a.) Buku

Panduan Ebtanas SMK, Jakarta: Dikmenti.

Dick, W., and Carey, L. (1990). The Sistematic Design of Instruction : Third Edition, Glenview, Illionis: Scott, Foresman and Company

Dick, W. dan Reiser, Robert A. (1989). Planning Effective Instruction, USA: Allyn and Bacon.

Hamalik, O., (2003) Perencanaan Peng-ajaran Berdasarkan Pendekatan Sistem, Jakarta: Bumi Aksara.

Howell, KW. And Nolet, V. (1999) CurriculumBased Evaluation, United States: Peter Marshall.

Ibrahim, R. dan Syaodih Sukmadinata, N. (2003), Perencanaan Pengajaran, Bandung: Rineka Cipta.

Keeping Schoolls Open as Community Learning Centers. (1997), The 
ISSN: 1829-6750 Inovasi Kurikulum, Agustus 2009, Thn. 6. Vol 6 Nomor: 2

Evaluation Process,

(Download), Tersedia:

http://www.ed.gov/pubs/

Learn Centers/ append-

h.html (22 September

2008).

Rae, L. (2005), The Art of

Training Aids in Training

and Develop-ment:

EFFECTIVE

PLANNING, London:

Clutterbuck Associates.

Reece, L. and Walker, S.,

(1997). Teaching

Training and Learning: A

Practical Guide, Third

Edition, Sunderland:

Business Education

Publishers.

Stolovitch, Harold D. dan

Keeps, Erica J. (2003),

Engineering Effective

Learning, San Francisco:

Pfeiffer An Imprint of

Wiley. 